\title{
Effects of Integrated Plant Nutrient Management (IPNM) Practices on the Sustainability of Maize-based Hill Farming Systems in Nepal
}

\author{
Tejendra Chapagain \\ Faculty of Land and Food Systems, the University of British Columbia \\ 344-2357 Main Mall, Vancouver, BC V6T 1Z4, Canada \\ Tel: 1-604-822-9607/1-778-919-8769 E-mail: tejendra@interchange.ubc.ca \\ Gam B. Gurung \\ Forum for Rural Welfare and Agricultural Reform for Development (FORWARD) \\ POB: 11, Bharatpur-2, Kshetrapur, Chitwan, Nepal
}

\begin{abstract}
Maize is a staple summer crop grown in the hilly areas of Nepal, where the soil is fragile and fertility is declining over years due primarily to degradation of natural resource base, high rates of soil erosion, increased cropping intensity and inadequate replenishment of soil nutrients. Forum for Rural Welfare and Agricultural Reform for Development (FORWARD) with the financial support from Hill Maize Research Program (HMRP/ CIMMYT) conducted eight Integrated Plant Nutrient Systems (IPNS) trials, 16 Farm Yard Manure (FYM) improvement demonstrations and 16 conservation farming demonstrations each year through two women farmer groups since 2003 in Makawanpur District in order to raise the awareness of farmers on sustainable soil management practices through better utilization of locally available and external resources. The three years' trial results revealed that the maize crop with IPNS $\left(15 \mathrm{t} \mathrm{ha}^{-1} \mathrm{FYM}+60: 30: 30 \mathrm{NPK} \mathrm{kg} \mathrm{ha}{ }^{-1}\right)$ was better with respect to crop vigor and grain yields compared to the control treatment (farmers' practice with FYM and urea top dressing). The Improved cultivar with IPNS practices increased the grain yield by $64 \%$ ( $\mathrm{p}<0.01)$ compared to the Local cultivar under farmers' managed condition. The plots with IPNS also exhibited positive effects on the performance of millet, a subsequent crop in the local cropping systems. Farmers were well impressed that FYM along with a balanced dose of Nitrogen $(\mathrm{N})$, Phosphorus $\left(\mathrm{P}_{2} \mathrm{O}_{5}\right)$ and Potash $\left(\mathrm{K}_{2} \mathrm{O}\right)$ is necessary for increased crop yields. There was a good impression of farmers with improved method of FYM preparation in pits over their traditional method of FYM preparation on exposed heaps. Hedgerow system with napier, sunhemp and pigeon pea on terrace edges and riser, was introduced as a new technology to farmers. They have preferred this technology for soil conservation and forage for livestock feeding. These soil fertility management practices could also be extrapolated to the similar recommendation domain so as to promote sustainable soil management practices, and enhanced food security in the region.
\end{abstract}

Key words: Integrated Plant Nutrient Management (IPNM), Diamond trials, Conservation farming, Hedgerow system, Farm Yard Manures (FYM)

\section{Background Information}

Hill farming in Nepal is characterized by more conventional type where farmers mostly rely on a single option to replenish plant nutrients so as to produce grains for their family. It is a well-known fact that soil fertility management plays a vital role in increasing crop productivity and production to address the problem of food security and income generation of farming households. But the farmers have not adequately applied these measures to enhance overall system productivity because they are deprived of the access to resources, knowledge and skills on sustainable soil fertility management (FORWARD, 2006).

Decline in soil fertility has been reported due primarily to degradation of natural resource base, high rates of soil erosion, increased cropping intensity and inadequate replenishment of soil nutrients (Vaidya et al. 1995; Joshy and Pandey, 1996; Sherchan and Gurung, 1996). The HMRP survey results revealed that maize receives an

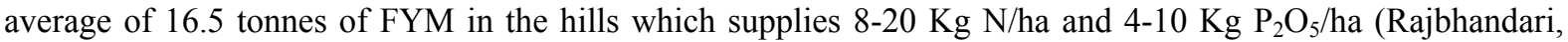
2000). Similarly, Rajbhandari (2000) reported that maize only receives $26 \mathrm{~kg} \mathrm{~N} / \mathrm{ha}$ from urea, $9 \mathrm{~kg} \mathrm{~N} / \mathrm{ha}$ and 4 $\mathrm{kg} \mathrm{P}_{2} \mathrm{O}_{5} /$ ha from Diammonium Phosphate (DAP), and $3.6 \mathrm{Kg} \mathrm{K} \mathrm{K}_{2} \mathrm{O} / \mathrm{ha}$ from Murate of Potash (MOP). 
Whatsoever, it is obvious that the present rate of FYM and fertilizer application doesn't meet the nutrient requirements $\left(80-100 \mathrm{Kg} \mathrm{N}, 20-50 \mathrm{Kg} \mathrm{P}_{2} \mathrm{O}_{5}\right.$ and $20-30 \mathrm{Kg} \mathrm{K}_{2} \mathrm{O}$ per ha) for the maize crop as suggested by Pandey (2000).

Soil fertility decline due to soil erosion and nutrients losses through runoff and leaching is a serious problem in the hills of Nepal (Tripathi et al. 1999 and 2000; Gardner et al. 2000; Paudyal et al. 2001). The annual loss of soil from agricultural plots ranges from a mere $0.1 \mathrm{t} / \mathrm{ha}$ to as high as $105 \mathrm{t} / \mathrm{ha}$ (Chalise and Khanal, 1997). Carson (1992) calculated a nutrient loss of 300-kg organic matter; $15-\mathrm{kg}$ nitrogen, $20-\mathrm{kg}$ phosphorus, and $40-\mathrm{kg}$ potassium by assuming soil loss of $20 \mathrm{t} / \mathrm{ha}$ from a marginalized rain fed agricultural land in the mid-hills. A loss of 1-mm topsoil has been estimated to cause loss of $10-\mathrm{kg}$ nitrogen, $7-\mathrm{kg}$ phosphorus and $15 \mathrm{~kg}$ of potassium per hectare (Carson, 1992). It was estimated that 1.8 million tones of plant nutrient are removed from soil by crop harvest and soil erosion, and only 0.3 million tones (16 percent) are replenished by organic and inorganic fertilizers (MOPE, 2001). At the same time, in the mid-hill regions, rice-growing farmers have benefited from the accumulation of eroded sediments (Shah, 1996; Schreier and Shah, 2000).

In recent years, application of chemical fertilizers is gradually increasing, as farmers now know the importance of fertilizers in crop production. But, a single option is not enough to replenish lost plant nutrients. Through the adoption of IPNS, using combinations of available nutrient sources, with proper timing and methods of application, in maize based systems are a right strategy. IPNS integrates all possible means of soil and crop management practices for soil fertility management with emphasis on locally available resources. The basic concept of IPNS is the judicial and efficient use of organic and inorganic fertilizers to meet crop needs based on a nutrient budget.

In the past many years, recommendations have been made based on soil fertility trials in maize but the adoption of technologies by farmers is minimal and fragmented. One of the reasons for low adoption of soil fertility related technologies is a lack of farmers' participation in the research process, particularly in the area of technology selection. In light of the above, this study was conducted in the mid-hill areas of Makawanpur district for four years in order to assess sustainable soil management practices for increasing soil fertility, maize productivity, and farmers' capacity through the adoption of IPNS practices.

\section{Research Methodology}

Farmers conducted the demonstrative research and extension activities themselves in a participatory approach for technology verification and dissemination with technical facilitation from specialists and field technicians. The farmers were actively engaged in the planning, implementation, monitoring, and evaluation processes.

The IPNS activities in the first year were initiated on a small-scale pilot basis. Women farmer groups in Tistung (Chandi Devi women group Tistung-2, Malagiri) and Bhainse (Luxmi women group, Bhainse-3, Amchaur) Village Development Committees (VDCs) were supported with soil management activities on potato-maize and maize-millet systems. In the second year, the project activities were continued with the same groups in Bhainse and Tistung, and were expanded to two more VDCs, Markhu (Devesthan women group, Markhu-1, Sarbhang) and Nibuwatar (Lali Gurans women group, Nibuwatar-8, Chiuri Bagaincha). In addition, the project activities in the third and fourth year were again expanded to include Nibuwatar (Chetansil group) and Bhimphedi (Hariyali group) VDCs. All group members were farmers with less than six months' food sufficiency in a year.

\subsection{IPNS trial on maize/millet system}

Trials using a maize/millet system were conducted at mid altitude domain of the aforementioned VDCs. A total of six farmers, three from each group collaborated on the planning of this activity. The trials were conducted in six replications across farms with four treatments; i) Improved cultivar + IPNS (15 t/ha FYM + 60:30:30 kg/ha NPK + lime as per the recommendation of soil lab, ii) Improved cultivar + farmer's practice, iii) Local cultivar + IPNS (15 t/ha FYM + 60:30:30 kg/ha NPK + lime as per the recommendation of soil lab, and iv) Local cultivar + farmer's practice. The plot size was $50 \mathrm{~m}^{2}$ for each treatment and the seed was broadcasted at the rate of 35 $\mathrm{kg} / \mathrm{ha}$. The selected trial sites were nearly homogenous with respect to the slopes and fertility gradient. Composite soil samples were taken from each farm/sites and sent to a laboratory for analysis. The soil in the demonstration plots was primarily sandy loam with a $\mathrm{pH}$ of 5 to 5.5. Therefore, it was treated with agri-lime before 15 days of trial conduction as suggested by the soil testing lab.

Maize in the trials was planted during normal planting season for the area. The Improved cultivar in the trial plot was Rampur Composite (seeds from National Maize Research Program, Rampur). The Farmers' Local cultivar used was collected from the progressive farmers cultivating the same varieties for 8 years. FYM, along with full doses of $\mathrm{P}_{2} \mathrm{O}_{5}$ and $\mathrm{K}_{2} \mathrm{O}$ and half dose of $\mathrm{N}$, was applied with IPNS practices basally at maize planted planting 
time. The remaining $\mathrm{N}$ was top dressed at two split doses; once at knee high stage and the other at tasseling stage. Maize from the trial plots was ready to harvest between 98 to 106 days after sowing. The other intercultural operations were conducted as per the treatments' need.

Observations were recorded on days to germination (50\% and 100\%), days to tasseling (50\% and $100 \%)$, days to harvest, response to disease and pests, number of ears per plant, and other yield attributing characters. The grain yield was than determined by using the following formula (Tiwari et. al. 2006).

$$
\text { Grain yield }(\mathrm{kg} / \mathrm{h})=\frac{\text { weight of dehusked ears }}{\text { harvested area }\left(\mathrm{m}^{2}\right)} \times \frac{100-\text { moisture content }(\%)}{85} \times 0.8 \times 10000
$$

Where, $0.8=$ shelling percent, which is assumed to be constant @ $98 \%$

\subsection{Conservation farming demonstrations}

Eight leader farmers from each group collaborating for IPNS trials conducted a total of sixteen conservationfarming demonstrations each year. Conservation farming technology included hedgerows of napier, and pigeon pea (in alternate rows) on terrace edges with intercropping of grain legumes (cowpea, soyabean, mungbean) under maize.

\subsection{FYM preparation demonstrations}

Eight leader farmers from each group collaborating for IPNS activities had conducted a total of sixteen FYM preparation demonstrations each year using the improved method. The farmers had followed the pit method where FYM materials were covered with black plastic sheet to conserve heat and moisture, and protect FYM from intense rain and sun. Emphasis was given on incorporation of cattle urine with FYM materials, application of Effective Micro-organism (EM) and lime in the pit. Observations were made on days taken for maturation, physical properties, and $\mathrm{N}, \mathrm{P}_{2} \mathrm{O}_{5}$ and $\mathrm{K}_{2} \mathrm{O}$ content of FYM.

\subsection{Data analysis}

Data were compiled and subjected to mean calculation and analysis of variance using Microsoft Excel and MSTAT-C software. Mean separation was done by LSD, and simple correlations were run between selected parameters using Statistical Package for Social Science (SPSS) software wherever necessary.

\section{Results}

\subsection{IPNS diamond trial on maize-millet system}

\subsubsection{Effects of IPNS on crop vigour}

A positive crop response was clearly observed in both varieties planted with IPNS practices versus Farmer's practice (Table 1). Major differences were observed in terms of biomass, color, plant height, crop vigour and consequently, grain yield. Farmers preferred Rampur Composite cultivar for good vigour and shorter plant height over the Local cultivar. Moreover, days to germination and tasseling also varied accordingly with the treatments but not significantly. Some barren plants were observed in the Local cultivar with farmers practice. Farmers also reported that plants were vigorous with larger cobs in IPNS plots. The incidence of insects and diseases was not observed except for tiger beetle and southern leaf blight, but both were far below the Economic Threshold Level (ETL). Plant stand in the Local cultivar was lower than Rampur Composite due to poor emergence.

\subsubsection{Effects of IPNS on grain yield}

Grain yield data of maize from the trial plots are presented in Table-2. The average grain yield was significantly higher in IPNS plots (5.8 t/ha and $4.9 \mathrm{t} / \mathrm{ha}$ respectively in the plots with Improved and Local varieties compared to the plots with farmers' level of management $(4.3 \mathrm{t} / \mathrm{h}$ and $3.5 \mathrm{t} / \mathrm{h}$ respectively in the plots with Improved and Local cultivars) (Table 2). Moreover, maize yield was increased $25-30 \%$ by adopting only IPNS practices over Farmers' practices for both varieties. The combination of IPNS and Improved cultivar produced $64 \%$ more yield (5.8 t/ha) compared to the Farmers' practice and Local cultivar (3.5 t/ha). Farmers have an impression that using a balanced dose of FYM and chemical fertilizers (urea, DAP and MoP) is important for higher crop yields. Also, the analysis of variance showed a significantly higher yield of Rampur Composite than the Local cultivar. Therefore, the farmers were enthusiastic to multiply the seeds of Improved cultivar (i.e., Rampur Composite) during coming season. 


\subsubsection{Effects on the subsequent [following] crops}

These trials were designed to demonstrate the effect of IPNS practices on a maize based cropping system i.e., planting of millet after harvesting of maize, the dominant cropping pattern adopted by the farm communities in some of the hilly areas of Makawanpur district. The plots, previously used for the IPNS diamond trial with maize, were used for the experiment. Both empirical evidence and farmers' preference, combined through matrix ranking, revealed that IPNS could greatly contribute to the production and productivity of subsequent crops (Table 3). As a result of aforementioned demonstrations, consensus has been developed among the maize-millet growers about the necessity of adopting IPNS in their cropping systems.

\subsection{Conservation farming demonstration}

Over 100 farmers in the project areas were made aware of the technological aspects of conservation farming and involved in various aspects of project implementation such as on-the-field demonstrations, on site coaching etc. Almost all of the collaborating farmers have adopted conservation-farming practices for an area of approximately one ropani $\left(508 \mathrm{~m}^{2}\right)$ after participating in the project activities. The most common plants used by farmers' communities in the project VDCs were napier, pigeon pea, mendola, and sunhemp planted under a hedge row system. All the participating farmers preferred napier for hedge rows soil conservation and livestock feeding, and pigeon pea as a optional pulse crop. In addition, an unexpected benefit was realized as farmer groups residing in nearby areas also showed enthusiasm in adopting the abovementioned technology.

Also, the group members not given direct material support also observed the demonstrations conducted by collaborating farmers and initiated the technology in their fields too. It could be expected that the leader farmers will also disseminate the technology to other neighboring farmers in respective VDCs in the following years.

\subsection{FYM preparation demonstrations}

A total of sixteen FYM preparation demonstrations, each year, were conducted in two project VDCs. The leader farmers from two farmer groups conducted FYM preparation demonstration using the improved method. Farmers prepared a pit $6 \mathrm{ft} \times 3 \mathrm{ft} \times 3 \mathrm{ft}$ to compost the FYM. Animal bedding and cattle dung were deposited in layers. Some locally available green vegetative materials were also added to the pit. Agricultural lime and EM was also added on each layer. Some farmers also added cattle urine. FYM pit was filled and covered with a black plastic sheet to protect the compost from rainwater and direct sunlight. Through the demonstration plots, additional group members were encouraged to create their own FYM preparations. A total of 76 farmers in Tistung, Bhainse, Markhu, Nibuwatar and Bhimphedi, beyond the direct support of this project, also implemented this technology on their farms. Farmers perceived it as a viable alternative to chemical fertilizers for vegetable crops on the basis of the first year's demonstration.

The effect of EM was clearly observed to hasten the rate of FYM decomposition. FYM prepared by the improved method is ready for field application 50 days after pit filling whereas it was still immature under farmers' managed conditions. Farmers observed major differences in days to maturity, color and quality of FYM between Improved vs Farmers' practice. The lab results also revealed that FYM prepared by improved methods has a higher percentage of nitrogen $(1.1 \%)$, phosphorus $(0.7 \%)$ and potassium $(0.8 \%)$ compared to the farmers' prepared FYM $(0.6 \%, 0.3 \%$ and $0.4 \%$, NPK respectively).

\section{Discussion}

In Nepal, very little research has been conducted on integrated plant nutrient management practices, especially in hill agricultural systems. However, the observed effects of IPNS on yield and soil conservation are supported by the work of a number of researchers.

Maize yields under Improved and Farmers' management systems were found to be very similar to the research station yield, and were higher than the average productivity in the average farmers' field. Average maize yield using the Local cultivar under Farmers' management was 3.5 t/ha which was nearly 2.3 tons lower than the yield obtained with IPNS management and Improved cultivar. Paudyal et al. (2001) reported a large variation in maize productivity ranging from a minimum of $0.36 \mathrm{t} / \mathrm{ha}$ to a maximum of $5.13 \mathrm{t} / \mathrm{ha}$ in the different agroecologies within the midhills. The average yield of Local maize in the mid-hill agro-ecologies was reported to be from $1.35 \mathrm{t} / \mathrm{ha}$ to $2.36 \mathrm{t} / \mathrm{ha}$, and that of hybrid maize to be from $3.8 \mathrm{t} / \mathrm{ha}$ to $5.06 \mathrm{t} / \mathrm{ha}$ with an average yield of $4.43 \mathrm{t} / \mathrm{h}$. They also reported an average yield of Improved open pollinated varieties of maize in the mid-hill and high-hill were $18 \%$ and $20 \%$ higher than the Local maize.

Seed, fertilizers, and manure are the major inputs used by farmers in the study sites. Seed rate is as high as $60 \mathrm{~kg}$ per ha in the eastern midhills, and this practice is mainly to ensure that enough plants develop despite possible low germination rates and pest problems. In other parts of the mid and high-hill, it ranges from 25 to $35 \mathrm{~kg} / \mathrm{ha}$ 
(Paudyal et al. 2001). Similarly, the average use of fertilizer in the eastern midhills is $90 \mathrm{~kg} / \mathrm{ha}$ comprised of 57 $\mathrm{kg}$ urea, $30 \mathrm{~kg}$ DAP and $3 \mathrm{~kg}$ Potash, whereas only $36 \mathrm{~kg} / \mathrm{ha}$ fertilizer is used in the mid-western and far-western midhills. In the Terai, where adoption of Improved technology is higher than the hills, $84 \mathrm{~kg} / \mathrm{ha}$ urea, $62 \mathrm{~kg} / \mathrm{ha}$ DAP and $32 \mathrm{~kg} / \mathrm{ha}$ potash is used. Despite poor access, farmers in the high-hill reported using $37 \mathrm{~kg}$ fertilizer per ha in maize fields on average (Paudyal et al. 2001). It is thus obvious that the present rate of FYM and fertilizers application by farmers is below the nutrient requirements for the maize crop. Pandey (2000) also conducted an experiment with maize fertilizer management, and has recommended a general rate of $80-100 \mathrm{~kg}$ $\mathrm{N}, 20-50 \mathrm{~kg} \mathrm{P}_{2} \mathrm{O}_{5}$ and 20-30 $\mathrm{kg} \mathrm{K}_{2} \mathrm{O}$ per ha for maize in the mid-hill.

Das and Bauer (2009) observed a declining trend of yield in all cropping systems except for maize under hedgerow systems. The most rapid decline was observed in thee conventional system due to heavy loss of soil nutrients and organic matter caused by the soil erosion which reduced yield by $44 \%$ over 30 years. Nelson et al (1997) also found significant yield decline in maize crops under continuous cropping system in the uplands of Philippines which have the similar topographic condition to that of mid hills of Nepal. It is also evident that yield is very specific to the soil type and the amount of inorganic and organic fertilizers applied thereby giving farmers the opportunity for maize yield increases via better nutrient management.

\section{Summary and Conclusion}

The collaborating farmers in the aforementioned VDCs of Makawanpur district observed the effects of IPNS with better crop vigor (plant canopy and leaf color) and higher crop yields (multi-ears with large and bold grains) compared to the control plot i.e., Farmers' practice. They have now realized that both IPNS and Improved varieties are equally important for increased yields. Farmers were impressed that FYM, along with balanced dose of $\mathrm{N}, \mathrm{P}_{2} \mathrm{O}_{5}$ and $\mathrm{K}_{2} \mathrm{O}$, is necessary for increased crop yields. Maize yield was increased up to $25-30 \%$ by only adopting IPNS practices over Farmers' practices in both of the cultivars. The combination of IPNS and Improved cultivar produced 64\% more yield compared to the Farmers' practice and Local cultivar.

Farmers also observed that FYM prepared by the Improved method (i.e., pit method using EM and lime, and covered with black plastic sheet) was better in terms of maturity and quality (nutrient composition) compared to the traditional practices. They have also realized the need of growing hedge-rows of grasses on their sloping terraces for soil conservation. They preferred napier and pigeon pea for hedge-rows as these forage grasses can be used for soil conservation, livestock feeding, and as a pulse crop.

Almost all farmers realized the technologies promoted were low-cost and complementary to their normal practices for enhancing overall system productivity. They are now convinced on the effectiveness of IPNS on major cereals (i.e., maize and the following crop, millet) and perceived it as a prime factor to improve food security and livelihoods of the disadvantaged groups in the rural community. It is apparent that the project in the working VDCs has greatly raised the awareness of farmers on soil fertility management and they are now in the process of adopting and scaling up these technologies with only an as-need technical support.

Above all, the participatory approach has been found effective both for technology verification and dissemination to farmers through demonstrative research and extension activities. It has increased their awareness on the importance of soil fertility management for increasing crop productivity and production. The collaborating farmers have shown positive impressions on the balanced use of chemical fertilizers, improvements in traditional method of FYM preparation, and conservation farming on cultivated hill slopes.

\section{Acknowledgements}

FORWARD greatly acknowledges HMRP and its team for financial support and cooperation. Also, National Maize Research Program (NMRP), Rampur and Plan Makawanpur deserve special thanks for their technical collaboration and assistance. Sincere thanks are due to the members of farmers group of Bhimphedi, Nibuwatar, Bhainse, Tistung and Markhu VDCs of Makawanpur district for their kind efforts and active participation throughout the study periods.

\section{References}

Carson, B. (1992). The land, the farmer and the future: A soil fertility management strategy for Nepal. Kathmandu: ICIMOD occasional paper No. 21.

Chalise, S. R., \& Khanal, N. R. (1997). Erosion processes and their implications in sustainable management of watersheds in Nepal Himalayas. In A. Gustard, S. Blazkova, M. Brilly, S. Demuth, J. Dixon, H. V. Lanen, C. Llasat, S. Mkhandi, \& E. Servat (Eds.), FRIENDS' 97 - Regional hydrology: concepts and models for sustainable water resource management. Wallingford: IAHS publication, No. 246. 
Das, R., \& Bauer, S. (2009). Soil conservation in mountains of Nepal: Can mountain farmers achieve sustainability through technological innovations? Giessen: Department of Project and Regional Planning, Justus Liebig University.

FORWARD. (2006). Annual Progress Report on "Promotion of Integrated Plant Nutrition System (IPNS) in Maize-based Systems in the Hilly Areas of Makawanpur District". Bharatpur: FORWARD, Nepal.

Gardner, R., Kevin, M., Tripathi, B. P., Gaskin, S., \& Adams, S. (2000). Soil erosion and nutrient loss in the middle hills of Nepal 1996-1998. ARS, Lumle and SSD (NARC), and Queen Mary and Westfield College, University of London, United Kingdom.

Joshi, D. R., \& Pandey, S. P. (1996). An overview of Soil Fertility and Plant Nutrition Research in Nepal. In Proceedings of National Workshop on Soil Fertility and Plant Nutrition Management (pp. 19-26), 19-20 December, Lalitpur: SSD (NARC), DOA and FADINAP, Nepal.

MOPE. (2001). State of the environment Nepal (Agriculture and Forest). Kathmandu: HMG/Nepal and Ministry of Population and Environment.

Nelson, R. A., Cramb, R. A., Menz, K., \& Mamicpic, M. A. (1998). Cost benefit analysis of alternative forms of hedgerow intercropping in the Philippine uplands. Agroforestry Systems, 39, 241- 262.

Pandey, S. P. (2000). Current Soil Fertility Management Recommendations, Constraints and Opportunities for Maize Based Cropping Systems in the Hills of Nepal. In B. P. Tripathi, N. P. Rajbhandari \& J. K. Ransom, (Editors), Improved Soil Fertility Management for Sustainable Maize Production, Kathmandu: CIMMYT, HMRP and NARC.

Paudyal, K. R., Ransom, J. K., Rajbhandari, N. P., Adhikari, K., Gerpacio, R. V., \& Pingali, P. L. (2001). Maize in Nepal: production systems, constraints, and priorities for research. Kathmandu: Nepal Agricultural Research Council (NARC) and International Maize and Wheat Improvement Center (CIMMYT).

Rajbhandari, N. P. (2000). Declining Soil Fertility Constrains Maize Production in the Hills - A Review of Recent Surveys of Farmers Practices, Perceptions and Conceptualizing a Basis for proper Targeting of Maize Research in the Hills: In B. P. Tripathi, N. P. Rajbhandari \& J. K. Ransom, (Editors), Improved Soil Fertility Management for Sustainable Maize Production, Kathmandu: CIMMYT, HMRP and NARC.

Schreier, H., \& Shah, P. B. (2000). Soil fertility status and dynamics in the Jhikhu and Yarsha khola watershed. In A. Richard, S. Hans, S. Brown \& P. B. Shah (Eds.). The people and resource dynamics project: the first three years (1996-1999). Kathmandu: ICIMOD, Nepal.

Shah, P. B., (1996). Soil fertility and erosion based unsustainability concerns in Nepal. In D. Joshi (Ed.), Workshop on soil fertility and plant nutrition management. Kathmandu: Soil Science Division, NARC.

Sherchan, D. P., \& Gurung, G. B. (1996). Sustainable Soil Management Issues in the Eastern Hills of Nepal: PAC Experience. In Proceedings of National Workshop on Soil Fertility and Plant Nutrition Management (pp. 27-41), 19-20 December, Lalitpur: SSD (NARC), DOA and FADINAP, Nepal.

Tiwari, T. P., Poudel K. R., Ferrara G. O., KC, G., \& Katuwal, R. B. (2006). Guidelines for farmers' managed diamond trial. Kathmandu: HMRP, CIMMYT and NMRP, Nepal.

Tripathi, B. P., Gardner, R., Mawdesley, K. J., Acharya, G. P., \& Shah, R. P. (1999). Soil erosion and fertility losses in the western hills of Nepal: an overview. Lumle seminar paper No 99/9. Kaski: Agricultural Research Station (ARS).

Tripathi, B. P., Shrestha, S. P., \& Acharya, G. P. (2000). Summary and updating with 1999 season soil and nutrient losses from bari land terraces in the western hills of Nepal. Lumle technical paper No 2000/3. Kaski: Lumle Agricultural Center (LAC).

Vaidya, A. K., \& Joshi K. D. (1995). An investigation of Soil Fertility Issues in the Hills of Nepal with Systems Perspective. In Formulating a Strategy for Soil Fertility Research in the Hills of Nepal (pp 83-103). Proceedings of a Workshop held in Lumle Agricultural Research Centre, Pokhara, Nepal; 17-18 August, 1995. Pokhara: LAC, Nepal and NRI, UK. 
Table 1. Matrix ranking of growth parameters under different treatments during the cropping season

\begin{tabular}{|l|c|c|l|}
\hline \multirow{2}{*}{ Treatments } & \multicolumn{2}{|c|}{$\begin{array}{c}\text { Ranking by farmers } \\
\text { group }\end{array}$} & \multirow{2}{*}{ Key Indicators } \\
\cline { 2 - 3 } & Hariyali & Chetansil & \\
\hline IV + IPNS & I & I & More height and girth with dark green leaves and multi ears \\
\hline IV + FP & III & III & Thin and yellowish plants; ear with partial grain \\
\hline Local + IPNS & II & II & $\begin{array}{l}\text { More height and girth with dark green leaves but single ear in } \\
\text { most cases }\end{array}$ \\
\hline Local + FP & IV & IV & $\begin{array}{l}\text { Thin and dwarf yellowish plants with more barren plants (less ear } \\
\text { formation) }\end{array}$ \\
\hline
\end{tabular}

Source: Inter group visit and interaction reports

Table 2. Average grain yields from IPNS and control treatments

\begin{tabular}{lll}
\hline Treatments & Plant population $\left.\mathbf{( 9 ~}^{\mathbf{2}}\right)$ & Mean grain yield $\mathbf{( k g} / \mathbf{h a})$ \\
\hline T1 $\left(\mathrm{IV}+15 \mathrm{t} \mathrm{ha}^{-1} \mathrm{FYM}+60: 30: 30 \mathrm{~kg} \mathrm{ha}^{-1} \mathrm{NPK}\right)$ & $48-50$ & $5863 \mathrm{a}$ \\
$\mathrm{T} 2(\mathrm{IV}+$ farmers' practice) & $50-52$ & $4320 \mathrm{c}$ \\
$\mathrm{T} 3\left(\mathrm{LV}+15 \mathrm{t} \mathrm{ha}^{-1} \mathrm{FYM}+60: 30: 30 \mathrm{~kg} \mathrm{ha}^{-1} \mathrm{NPK}\right)$ & $43-45$ & $4923 \mathrm{~b}$ \\
$\mathrm{~T} 4(\mathrm{LV}+$ farmers' practice) & $40-42$ & $3573 \mathrm{~d}$ \\
\hline F-Test & & $*$ \\
Cultivar & & $* *$ \\
Interaction & & $\mathrm{NS}$ \\
$\mathrm{CV}(\%)$ & 7.28 \\
$\mathrm{SE} \pm$ & & 138.87 \\
\hline
\end{tabular}

* Significant ** non-significant

Means within the column followed by the different letter differed significantly by LSD at $\mathrm{p}=0.01$

Note: IV = Improved cultivar; LV = Local cultivar

Table 3. Matrix ranking of the millet performance under different plots during the cropping season

\begin{tabular}{|l|c|c|l|}
\hline \multirow{2}{*}{ Plots } & \multicolumn{2}{|c|}{$\begin{array}{c}\text { Ranking by farmers } \\
\text { groups }\end{array}$} & \multicolumn{1}{|c}{ Key Indicators } \\
\cline { 2 - 3 } & Hariyali & Chetansil & \\
\hline IV + IPNS & I & I & $\begin{array}{l}\text { More height and girth with dark green leaves, long and erect panicles } \\
\text { with more and bold seeds }\end{array}$ \\
\hline IV + FP & II & II & Thin and dwarf yellowish plants, panicles with partial and small grain \\
\hline Local + IPNS & I & I & $\begin{array}{l}\text { More height and girth with dark green leaves, long panicles with more } \\
\text { and bold seeds }\end{array}$ \\
\hline Local + FP & II & II & Thin and dwarf yellowish plants, panicles with partial and small grain \\
\hline
\end{tabular}

Source: Inter group visit and interaction reports 